\title{
CORRIGENDUM
}

\section{Against the odds: extraordinary recovery from complete cauda equina syndrome following L3 fracture. Time still matters}

Silvia Antiga, Klint Asafu-Adjaye, Fahim Anwar and Pierluigi Vergara

Spinal Cord Series and Cases (2017) 3, 17001; doi:10.1038/scsandc.2017.1; published online 4 May 2017

Correction to: Spinal Cord Series and Cases (2016) 2, 16027. doi:10.1038/scsandc.2016.27; published online 10 November 2016

The authors apologise for any inconvenience caused.

Since the publication of this article, the authors have noticed that co-author Klint Asafu-Adjaye's name was spelled incorrectly. The article PDF and html have been corrected. 